\title{
Lighthouses for biodiversity: prospects and challenges for zoological university museum in Indonesia
}

\author{
Ganjar Cahyadi ${ }^{1, *}$, Rahman Rasyidi $^{2}$, and Dikdik Permadi $^{2}$ \\ ${ }^{1}$ Museum Zoologi SITH ITB, Jalan Let. Jend. Purn. Dr. (HC) Mashudi No. 1, Jatinangor, Kabupaten Sumedang, Indonesia, \\ 45363 \\ ${ }^{2}$ School of Life Sciences and Technology, Institut Teknologi Bandung, Labtek XI Building, Jalan Ganesha No. 10, Bandung, \\ Indonesia 40132
}

\begin{abstract}
University museums have been offering a great opportunity to study thematic collections. In zoology, it has been aiding the university biologist to keep safe extensive biodiversity collections from academic expeditions. When appropriately managed, this opens an opportunity for display, research, teaching, and outreach, especially for regions that may not have easy access to government-managed museums. However, Indonesian university museums have been positioned in a confusing situation in which university museums have limited opportunities to serve the main roles of museums. We use Museum Zoologi Sekolah Ilmu dan Teknologi Hayati, Institut Teknologi Bandung (MZSITH-ITB) as a study case. In this paper, we tried to explore the current roles of university museums being served and explore the prospects and challenges for university museums. Concurrent triangulation approach from desk evaluation, visitor analysis, and a semi-structured interview was conducted to see the current roles of MZSITH-ITB and prospects and challenges in the future. In conclusion, clear general procedures to standardize the collection management are urgently needed, so university museums can have a degree of independence to collect and study objects and collections. This can allow easier data integration and specimen sharing in which the museums can work together to shed some light on Indonesian biodiversity.
\end{abstract}

\section{Introduction}

Prior to creating a framework for this study, the historical change of collections and museums might be interesting to review. First public museums of natural history were founded in Paris, 1635 [1, 2, 3], and the first university museum was founded in Basel, 1671 [2, 4]. In the beginning, collections and museums were merely private properties that could be used by the public to study. Although universities or academies owned collections and museums, so far, collections and museums purposes were to be a set of display only. Almost twenty years later, the modern management system of academic collections was first coined by the establishment of the Ashmolean Museum at Oxford University, England, in 1683 [2, 4]. Although collections and early museums can be traced back to the "cabinets of the curious" containing natural artefacts collected by the European nobles in the sixteenth to the seventeenth century, Ashmolean Museum introduced an official structure in which this museum was managed by a group of curators with a complete catalogue and regulation for both the academics and the visitors [2, 5]. Many universities and even public museums followed this system, changing the core idea of a museum itself. This role changed throughout time in which educational purposes for teaching and practical research were added. As mentioned before, museums at the time accommodated a larger body of academic staff, which taught collection-related lectures with a bigger number of students involved. With the new structure, the museum had changed into an academy itself and eventually providing services for research and teaching in the associated university. This association makes the difference with the public museums, even though the roles and managerial system might be similar $[2,6]$.

Following this historical account, we framed the roles of university museums into four categories $[2,6]$. First, the classical purposes of the museums itself are to collect and maintain academic collections. This role is heavily linked to university academics, as they are the provider of the collections of interest [7]. This role can also be expanded to display the collections for the public. Second, university museums were intended to support teaching and educational purposes. In this case, visitors were assumed to not only enjoy the collections

\footnotetext{
* Corresponding author: ganjar@sith.itb.ac.id
} 
as is but also to gather information and knowledge through provided details or detailed discussions with the museum curators. Third, university museums were also aimed to become a place for research itself where academics can collaborate with the curators to expand the knowledge based on their collections, either to collect more or to gain a deeper understanding of owned collections. Lastly, the museums can provide a professional consultancy that can be further than just a discussion. Depending on the theme of the museums, this role can vary to a very wide range. For instance, in Zoology, the museum curators are often able to provide a service to keep and maintain private collections, provide taxonomic books and literature, or even provide service to determine species of the collections [8].

Indonesian museums are ruled by Government Regulation No. 66, 2015, regarding Museums. This policy interestingly defines a museum by its functions: an institution which roles are to maintain, develop, utilize, and communicate its collection to society. The collection itself is distinguished into four categories which are things ('benda'; including natural and humanmade specimens), buildings ('bangunan'), and structure ('struktur'). Museums are also allowed to gather their own collection in reflection to its role as the developer of their own collections. In line with previously mentioned management roles of museums, Indonesian museums can utilize their collections by the form of educational outreach. In the term of service, it is only mentioned that museums can keep entrusted collections. For instance, natural history collections specifically on Zoology is kept and maintained by Museum Zoologicum Bogoriense (MZB) [9]. Starting from a role to collect and study insects in the surrounding agricultural areas, MZB has turned into the only specific authority to keep and maintain zoological specimens in Indonesia. MZB also serves the other three roles of a museum as mentioned previously, with a special link to the Indonesian Institute of Sciences (LIPI) as the scientific counterpart [10].

Apart from authorized museums, Indonesia also has university museums that are managed directly under the universities. At least 49 university museums from about 4445 universities [Handari 2019, pers.comm.; 11] in Indonesia have been listed and categorized into six groups: humanities and social science; arts; natural history; science and technology; memorial hall and archive; and biography (Yudhawasthi 2019, pers. comm.). However, it was not realized until recently that there are seven active zoological university museums revealed through a curator-museum staff colloquium in early 2019 (Yudhawasthi 2019, pers.comm.). The mentioned policy only regulates museums that are owned by the national government, regional government, indigenous community, or private sector. This caused an awkward situation for university museums because they are supposedly maintained by universities [12]. Therefore, it is unclear whether the policy might or might not rule over university museums as selected institutions. Even in the university structure itself, university museums might not have the same position as labs and libraries because most often university museums are obscurely managed by a small group of professors and curators to maintain materials for lectures and practical classes [12, Yudhawasthi 2019, pers. comm.]. This confusion caused a severe limitation of Indonesian university museums' independence and ability to serve its roles. It is not surprising that university museums do not have their own research projects, although this is one of the core functions of modern university museums (Yudhawasthi 2019, pers. comm.). This issue was also realized linked through a curator and museum staff colloquium in early 2019 in which they gain a new network that has not been structured before (Cahyadi 2019, pers. obs.). With a thorough discussion on prospects and challenges, they realized some actions needed to adapt and survive for future Indonesian research.

To further investigate this phenomenon, the objective of this study was to explore how the roles of Indonesian university museums have been currently served. A study case was conducted in Museum Zoologi Sekolah Ilmu dan Teknologi Hayati, Institut Teknologi Bandung (MZSITH-ITB). As one of the oldest university museums in Zoology, MZSITH-ITB might reveal how the management of the university museum has changed over time based on the four roles of university museums. This study was also aimed to explore the prospects and challenges of Indonesian university museums are in the future. Desk evaluation, visitor data, and semi-structured interviews were utilized to answer these aims with a concurrent triangulation approach.

\section{Material and Methods}

The case study method that approached by Yin [13] applied to reveal the deep entity of MZSITH-ITB. The subject of this paper focuses on the relevance of MZSITH-ITB to the basic roles of the university museum, namely: 1) storage and curation; 2) research; 3) education; and 4) service [2, 14]. These functions then become the framework to elaborate on the prospects and challenges of the MZSITH-ITB in the future.

The data collected comes from the desk evaluation of museum documents [15] in the last two years (20172019), after the MZSITH-ITB was first revitalized. The data used consists of specimen collections, museum visitation, and determination services. These data are supported by concurrent triangulation [16] using interviews with several stakeholders involved in museum activities e.g. Head of the Museum, museum visitors, clients of determination service. The semi-structured interviews were used [17], guided to topics regarding university museum roles and functions that embedded with MZSITH-ITB.

\section{Results and Discussion}

Museum Zoologi SITH ITB was founded in the 1950s to properly collect and preserve animal specimens that were utilized for research and education in Zoology. Specimens were collected by European and North American researchers that did an extensive biodiversity 
study in Indonesia in 1940-1950. As a part of a collaboration, these collections were kept and maintained in the Biology Department (now School of Life Sciences and Technology) of Institut Teknologi Bandung. In 1960-2000, collections and maintenance were conducted by a curator, professors, and students with a keen interest in taxonomy and zoological study (Iskandar 2017, pers.comm.). At this time, MZSITH-ITB curator was considered an academic staff in the Division of Facilities and Infrastructure (see Figure 1). Therefore, the curator was not able to formally hold classes or conduct research because these activities must be done with the lecturers as the person in charge. Nonetheless, the collection grew as there were expeditions and field activities led by the faculty lecturers and collaboration with local zoo and hospital. MZSITH-ITB also collected more books and literature relevant to Indonesian biodiversity.

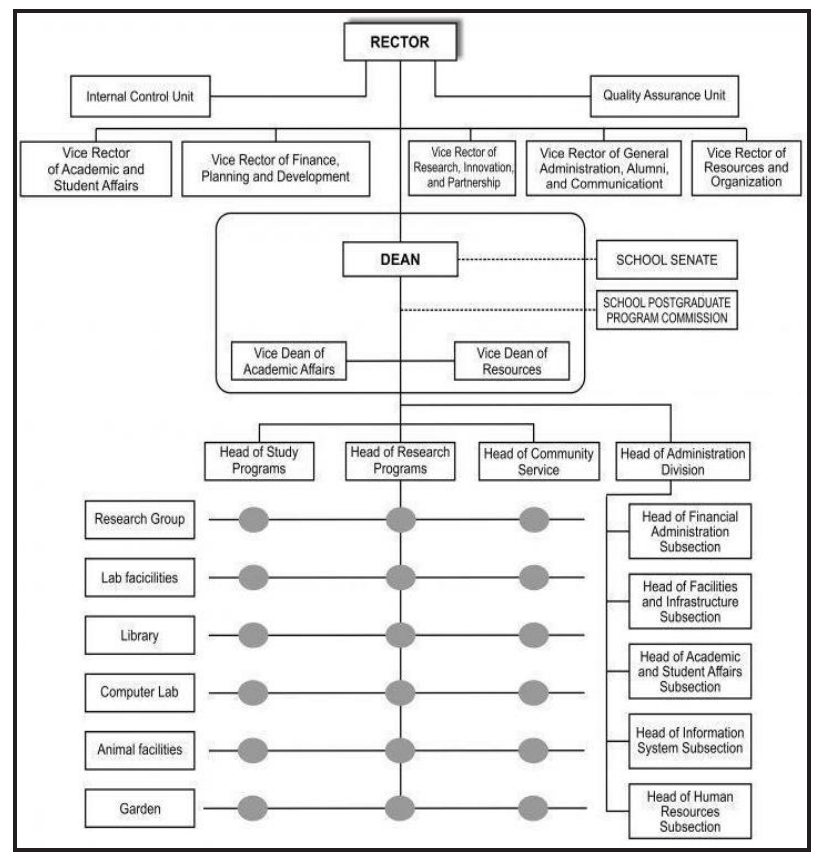

Fig. 1. Organization structure of Institut Teknologi Bandung. In this chart, the museum is categorized into lab facilities.

To date, ITB itself has grown into two major campuses: Bandung and Jatinangor [18]. MZSITH-ITB was relocated to the Jatinangor campus to allow bigger working space for the curator and bigger storage of specimens. There were about 2251 animal specimens of 1027 species stored in MZSITH-ITB, which includes invertebrates (372 specimens; 258 species), fishes (437 specimens; 307 species), amphibians (217 specimens; 92 species), reptiles (319 specimens; 175 species); birds (157 specimens; 141 species), and mammals (130 specimens; 54 species). These zoological collections consist of wet collections, dry collections (balgh and display), and skeleton articulations. However, fossils and animal organ collections, as well as old zoological illustrations, have not been listed. The management of specimens still depends on air conditioning and room humidity. Air conditioners have been set at the lowest temperature to maintain standard temperature for wet specimens, except for several tissue samples that have been stored in the $-4^{\circ} \mathrm{C}$ freezer. For the preservatives, formaldehyde-preserved wet specimens started to change to ethanol-preserved specimens. Unfortunately, the management of dry specimens still depends on manual cleaning.

On the term of research, currently, MZSITH-ITB is focused on creating a specimen database. The specimen catalogues have been generated to form a database. The data from the specimens have been extracted from available labels as well as identification based on taxa at the phylum, class or order level. The results of research on the specimen catalogue can be utilized as a basis for museum standardization based on owned collections. In addition, literature studies on the status of conservation of the collections (e.g. IUCN based) can be utilized to propose legal documents of the owned specimens or collections to relevant institutions, e.g. BBKSDA Jawa Barat.

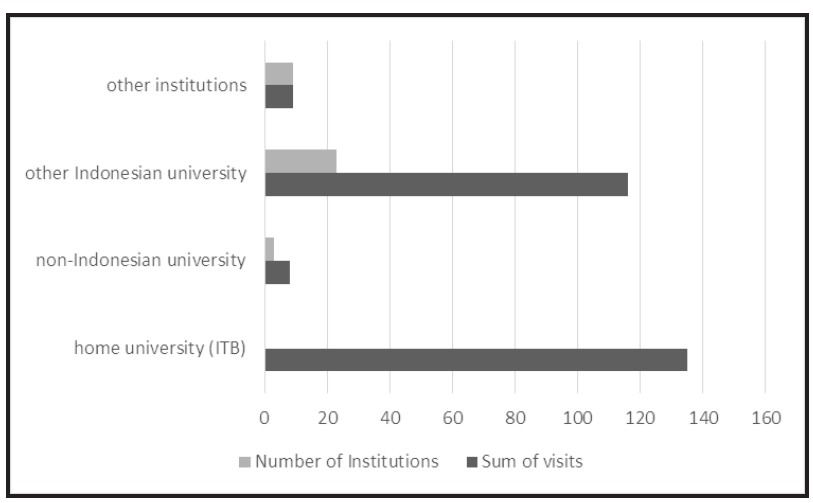

Fig. 2. Recapitulation of visitation by the institution to MZSITH-ITB.

MZSITH-ITB has been actively provided educational services for students in the last two years (2017 - 2019). MZSITH-ITB always receives at least two visitation programs proposed by students of the Biosystematics course (Biology Undergraduate Study Programs) and Zoological Taxonomy course (Forestry Engineering Undergraduate Study Programs) from the faculty. The visit was conducted in the context of animal specimen introduction and information sharing about the museum activity in general. The visitation represented as one of the outside-class materials given to students. It is hoped that the visit to MZSITH-ITB can provide a real picture of the topic that has been learned in class and the object that will be faced afterwards both in the classroom and in the field.

Based on the visitor analyses, the visitation to MZSITH-ITB in the last two years (2017-2019) has been dominated by home university visitors (ITB). Recapitulation of visits by institutions can be seen in Figure 2. Apart from home university (ITB), MZSITHITB has a large number of domestic university visits. It was noted that there are 23 domestic universities that have visited MZSITH-ITB, including Universitas Islam Bandung (Unisba), Universitas Jenderal Achmad Yani (Unjani), and Sekolah Tinggi Farmasi Bandung (STFB). 
Table 1. The origin of MZSITH-ITB visitors and their number of visits in the last two years (2017-2019).

\begin{tabular}{|l|c|}
\hline Address & Number of visits \\
\hline West Java Province & 249 \\
\hline Banten Province & 4 \\
\hline Central Java Province & 2 \\
\hline East Java Province & 2 \\
\hline East Nusa Tenggara Province & 1 \\
\hline DKI Jakarta Province & 2 \\
\hline International - Germany & 2 \\
\hline International - Japan & 1 \\
\hline International - Malaysia & 5 \\
\hline Total & 268 \\
\hline
\end{tabular}

The relationship between museum visitation and the basic roles of the university museum [2, 6, 14], is dominated by education and services (Table 2). The educational purpose is more dominated by regular visits ( $<30$ minutes) compared to the discussion ( $>30$ minutes). Moreover, determination services become the most widely used services. Based on these data, MZSITH-ITB seems connected to the specific target.

According to Table 1, Table 2, and Table 3, it can be assumed that the connection pattern of the museum and its clients or users is strongly determined by established networking. The result of the interview also shows the intention of clients to use museum services, e.g. museum visitation, determination services, came from interpersonal information. The relationship between MZSITH-ITB and its clients could be categorized as 'relationship marketing' [19] which is utilized client loyalty, interaction, and long-term engagement. This type of relationship is common in academic service providers, such as a museum or public Laboratorium. The identification of the interaction pattern between MZSISH-ITB and its clients should be used as the principal for MZSITH-ITB development.

According to the utility pattern of the museum, the main function of MZSITH-ITB seems directed to determination service. This service provided by MZSITH-ITB for agencies or institutions which submit applications for animal determination. The request is submitted to the Vice Dean of Resource then forwarded to the curator of MZSITH-ITB. The determination can proceed after the clients fulfilled the standard requirements for the samples. The curator (determinator) will notify the determination process to the clients that usually takes seven working days. After the determination is complete, the curator will make a letter of determination result to the Vice Dean of Resources that has been approved by the head of the museum. After the Vice Dean of Resource approves the results of the determination, the letter can be given to the clients.

Table 2. MZSITH-ITB visitors and their purpose of visits in the last two years (2017-2019).

\begin{tabular}{|l|l|c|}
\hline \multirow{3}{*}{ Function } & \multicolumn{1}{|c|}{ Purposes } & $\begin{array}{c}\text { Number of } \\
\text { Visits }\end{array}$ \\
\hline Education & Visit $(<30$ minutes $)$ & 124 \\
\cline { 2 - 3 } & Discussion $(>30$ minutes $)$ & 16 \\
\cline { 2 - 3 } & Practical Class & 1 \\
\hline \multirow{2}{*}{ Service } & Determination & 122 \\
\hline \multirow{2}{*}{ Others } & Specimen exchange & 1 \\
\cline { 2 - 3 } & Documentation & 1 \\
\hline
\end{tabular}

The animal determination results that have been proceeded in the last two years $(2017$ - 2019) are 105 samples divided into 16 Phylum or Class of animals (Table 3). Fish, brine shrimps, and nematodes are the most proposed animals for species determination. Pharmacy undergraduate students are the clients who most often determine the animal samples as one of the objects of research to get a bachelor's degree from their institutions.

As management improvements of the MZSITH-ITB continue to increase, as well as the number of visits from various parties and institutions, and also began to be recognized by the home university (ITB) in particular, the prospect based on specimen collection at MZSITHITB will be better in the future. Various contributions of specimen collections from home researchers as well as other institutions have been added to the diversity of specimens that previously not possessed by this museum. In addition, the trust of government institutions such as BKSDA (natural conservation institution of Indonesian Government) in depositing protected animal specimens is a breakthrough for this museum. The potential based on collections for research has risen, although minimal research has been conducted. Based on the specimen collections of MZSITH-ITB, numerous research topics can be generated from the field of taxonomy, anatomy, ecology, to animal diets. Even from the collection of animal specimens, the influence of humans on these animals in the past can also be revealed [20]. The great potential of the MZSITH-ITB as a "lighthouses" for research and education in the university is increasingly visible, particularly on the zoological study. This situation is followed by the increasing number of visitors so that the existence of MZSITH-ITB has increasingly known. This great potential also can be seen based on determination services. MZSITH-ITB, as the only zoological university museum in West Java, which provides animal determination services, could become a 
leading museum in term of those services. It also provides easy access that relied on by other institutions.

Table 3. The determined samples by MZSITH-ITB in the last two years (2017-2019).

\begin{tabular}{|c|c|c|}
\hline Phylum/Class & Num. of samples & Notes \\
\hline Actinopterygii & 22 & Fishes \\
\hline Branchiopoda & 13 & Brine shrimps \\
\hline Nematoda & 13 & Parasitic worms \\
\hline Amphibia & 10 & Amphibians \\
\hline Malacostraca & 9 & Crabs and shrimps \\
\hline Mammalia & 8 & Mammals \\
\hline Insecta & 7 & Insects \\
\hline Holothuroidea & 5 & Sea cucumber \\
\hline Gastropoda & 5 & Snails \\
\hline Anthozoa & 3 & Jellyfish \\
\hline Aves & 3 & Birds \\
\hline Reptilia & 2 & Reptiles \\
\hline Bivalvia & 2 & Bivalves \\
\hline Clitellata & 1 & Earthworms \\
\hline Eurotatoria & 1 & Rotifer \\
\hline Cubozoa & 1 & Jellyfish \\
\hline Total & 105 & \\
\hline
\end{tabular}

In general, the study on university museum in Indonesia still lacks compared to the governmental museum [21, 22] or private museum [23], although the challenges that faced by this museum are enormous [24]. MZSITH-ITB also faces great challenges. The legal aspect of the museum, as well as collections, must be prioritized to keep these assets safe for future researches and education programs. In addition, with the current management of the museum, those programs have to be efficiently prepared by the curator, although the implementation tends to be hard. Minimal acknowledgement from home university (ITB) also is a great challenge. Supports from the core of institutions are extremely needed to increase the motivations for the museum staff [25].

\section{Conclusion}

The MZSITH-ITB, as one kind of university museum in Indonesia, has shown great prospects based on collections, visitations, and services to support the function of the university as the center of research, education, and services for the public, particularly in zoological aspects linked to the faculty. Clear general procedures to standardize the collection management is urgently needed, so university museums can have a degree of independence to collect and study objects and collections. This can allow easier data integration and specimen sharing in which the museums can work together to shed some light on Indonesian biodiversity. Supports from the university or home institution are extremely needed to tackle the challenges faced by MZSITH-ITB.

This research is funded by the School of Life Sciences and Technology ITB and the Department of Human and Organization Development of ITB. We would like to express our gratitude to Musiana C. Yudhawasthi for constructive comments and discussions. Also, we would like to thank the interviewees: Sugi Yuniati, Tari Utami Refianti, Aziiz Mardarian Rosdianto, and Rina Ratnasih Purnamahati, who have been really helpful in our interviews.

\section{References}

1. G. Aymonin, http://www.universalis.fr/encyclopedie/botaniquesgardens/, [Accessed on 13 November 2019] (2019)

2. M.A. Lane, Annals of the Missouri Botanical Garden 8 , 536-545 (1996)

3. D.A. Rakow, S.A. Lee, Horticultural Reviews 43, 269310 (2015) https://doi.org/10.1002/9781119107781.ch05

4. J.R. Glaser, A.A. Zenetou, Museums: A Place to Work: Planning Museum Careers (Routledge, Oxon 2013)

5. E. Hooper-Greenhill, Museums and the Shaping of Knowledge (Routledge, London 1992)

6. P.J. Boylan, Museum management and curatorship 18(1), 43-56 https://doi.org/10.1080/09647779900501801

(1999)

7. C. Feigl, Academic Showcases: the Collections at the University of Vienna (Böhlau Verlag, Wien, 2016)

8. L. Grande, Curators: Behind the Scenes of Natural History Museums (University of Chicago Press, Chicago 2017)

9. A. Budiman, A.J. Arief, A.H. Tjakrawidjaya, Jurnal Iktiologi Indonesia 2(2), 51-55 (2002) https://doi.org/10.32491/jii.v2i2.277

10. Pusat Penelitian Biologi - LIPI (2019). http://www.biologi.lipi.go.id/zoologi/index.php/profilmzb [Accessed on 13 November 2019] (2019)

11. PDDIKTI, https://forlap.ristekdikti.go.id/perguruantinggi/homegrap hpt [Accessed on13 November 2019] (2016)

12. M.C. Lourenço, Museologia 3, 17-26 (2003)

13. R.K. Yin, Case Study Research - Design and Methods, 3rd edition (SAGE Publications Ltd, London, 2003)

14. A.K. Guthe, Curator: The Museum Journal 9(2), 103105 (1966) https://doi.org/10.1111/j.21516952.1966.tb01612.x

15. R. Kumar, Research methodology: A step-by-step guide for beginners, 3rd edition (Sage Publications Ltd, London 2011)

16. J.W. Creswell, Research Design (SAGE Publications Ltd, London, 2009) 
17. R. Edwards, J. Holland, What is qualitative interviewing? (Bloomsbury, London, 2013)

18. Institut Teknologi Bandung (2019). https:/www.itb.ac.id/multi-kampus [Accessed on 20 November 2019] (2019)

19. C. Madhavaiah, S.D. Rao, Asia Pacific Business Review 3(2), 64-76

(2007) https://doi.org/10.1177/097324700700300207

20. C.J. Schmitt, J.A. Cook, K.R. Zamudio, S.V. Edwards, Philosophical Transactions of the Royal Society $B$ 374(1763), 20170387

(2018) https://doi.org/10.1098/rstb.2017.0387

21. W.A. Panggabean, Peran Museum Negeri Provinsi Sumatera Utara Sebagai Daya Tarik Wisata Edukasi di
Kota Medan (Universitas Sumatera, Diploma Thesis Utara, Medan 2017)

22. A. Winaya, Amerta 33(2), 97-110 (2015) http://dx.doi.org/10.24832/amt.v33i2.218

23. A. Oktaviani, Peranan Museum Soeharto sebagai media pembelajaran sejarah (Universitas PGRI, Bachelor Thesis, Yogyakarta 2016)

24. P.B. Tirrell, Curator: The Museum Journal 43(2), 157180 (2000) https://doi.org/10.1111/j.21516952.2000.tb00011.x

25. M.C. Lourenço, B. Rothermel, A. Simpson, University Museums and Collections Journal 9, 7-8 (2017) 